\title{
ADVICE TO NEW INSTRUCTORS: SYSTEMS APPROACH
}

\author{
Olga Kosheleva \\ Ph.D. (Phys.-Math.), Associate Professor, e-mail: olgak@utep.edu \\ Vladik Kreinovich \\ Ph.D. (Phys.-Math.), Professor, e-mail: vladik@utep.edu \\ University of Texas at El Paso, El Paso, Texas 79968, USA
}

\begin{abstract}
A recent paper provided useful system-based approach to new school teachers. In this paper, we somewhat modify this advice so that it can be applied to new instructors on all levels, including new instructors at the university level.
\end{abstract}

Keywords: new instructors, system approach, teaching.

\section{Introduction}

A paper [1] presented at a recent online international conference provided a system-based analysis of the difficulties that new school teachers have. Some of the resulting advice is specific for K-12 education, but, in our opinion, a significant portion of this paper's ideas can be useful for new university instructions as well.

Some of the resulting advice may be common sense, but our experience of working with new university instructors shows that a significant portion of this advice is helpful.

\section{An Instructor: System Viewpoint}

Analysis. With whom and with what does the new instructor interact?

- The main objective of the Instructor is to teach, i.e., to interact with Students.

- $\mathrm{He} / \mathrm{she}$ also needs to stay update in his/her Discipline.

- As part of the job, the Instructor interacts with Colleagues and Administrators.

- Also, as a human being, he/she actively interacts with his Family and Friends.

Where difficulties come from. To adequately interact with someone:

- we need to understand the other person, and

- we need to use this understanding to select a proper way of communication. Some of the difficulties of the new instructor come from the lack of his/her understanding of others, some come from the lack of others' understanding of the new Instructor. 
However, understanding is not enough. Even when there is a full understanding, some difficulties may (and do) come from the inability to select a proper way of communication.

Let us describe these difficulties one by one.

\section{Difficulties Related to Instructor's Imperfect Under- standing of Students}

Which aspects are important. In the process of study, Students, in addition to interacting with the Instructor and relating to the Discipline, also interact with other Students, and with their own Family and Friends. To better understand the Student, we need to understand all these interactions.

Understanding a Student him/herself. New instructors received their degrees, this means that they were successful hardworking students. Often, they base their understanding of students they teach on the experiences that they themselves had as students.

However, this approach does not take into account that they were among the best students. An average student is not as hardworking and not as knowledgeable as they were in the past. As a result, often, on average, the new instructors' explanations are not as detailed as needed, their assignments are more complex that they should be, and their grading is - especially in the beginning - often too harsh.

Understanding Students' relation to the discipline. New instructors have a lot of enthusiasm for their discipline - otherwise they would not have spent many years studying it. They often implicitly assume that others have the same level of enthusiasm, but this is often not true.

Everyone understands that we need to raise students' interest when teaching to students who are not our majors, but even students who are our majors may not be that interested - and even if they are, they may be interested in something very specific.

One way to raise this interest is to emphasize applications of what we study. To better understand individual students' attitude, a good idea is to interview students at the beginning of the class, find out what interests them, and relate it to the course; this is known as the motivational interview.

When teaching required classes, it may be a good idea to ask students to connect to faculty and higher-level students in areas in which they are interested, so that they will help the students to find relation to the course (and it may be a good idea to give students extra points for this activity). After all, if the class is required, this means that there is some reason for this requirement. For example, when a Computer Science course is required for engineering students or a discrete math course for Computer Science students, this means that in the students' future studies, there are activities in which this knowledge will be useful.

Interest should be raised not just in a topic in general, it should be ideally raised before every class. Just like papers get informative attractive titles and attractive 
abstracts to be read more, it is a good idea to briefly explain, before every class, what will be the main topic and main result of this class - what new knowledge what new skills they will get. This way, if students are interested in the final result, they will pay more attention to (sometimes boring) technical details. This does not have to be class-by-class, sometimes, a new skill is learned in several classes.

Understanding Students' relation to other Students. Many classes involve and/or encourage groupwork. A new instructor has usually mastered this skill, but many students are still learning how to collaborate. Mistakenly, new instructors assume that students will somehow be able to effectively collaborate on a joint project. Often, this does not automatically happen, even when students form the groups themselves, with friends with whom they have some experience collaborating.

It is not enough to divide students into groups, we need to make sure that groups are productive. This is not easy, there are special techniques for this techniques that even experienced instructors may not know.

\section{Difficulties Related to Others' Imperfect Understanding of the New Instructor}

Starting instructors often have difficulties with teaching, which is understandable. The problem is that experienced instructors may not fully understand what exactly are these difficulties for each instructor - especially when they themselves have gone through this stage long time ago and may have forgotten what difficulties they had to overcome.

This situation can be improved from both ends: the new instructor should not hesitate to ask for help and advice, and more experienced instructors should not hesitate to offer such help and to encourage the new instructor to open up - e.g., by conveying their own past difficulties and how they overcame these difficulties.

A good idea is to have this feedback institutionalized; e.g., requires that in annual evaluations, instructors do not only brag about their successes, but also honestly emphasize their weaknesses - and either propose a plan to work on these weaknesses or ask for advice on this.

\section{Difficulties Related to Communication Skills}

In all the interaction, it is important:

- to take into account people's emotions, not just the substance matter; such "emotional intelligence" is not easy to learn, but it is vitally important in a teaching profession that is based on constant communication with other people;

- to be able to resolve conflicts; conflicts are inevitable, be it with students or with colleagues or with administrators, and learning conflict resolution skills is a must; 
- to be able to manage time; time management is our common weak point, we all overwork - often unnecessarily, and new instructors overwork even more; it is important to concentrate on truly important things, to learn how to say No to unimportant requests, to learn how to do things efficiently; the usual first step in time management is to write down, hour by hour, what tasks were performed - after a week, this will give a clear picture of how time is spent and what are the most time-consuming "black holes".

\title{
Acknowledgments
}

This work was supported in part by the US National Science Foundation grants 1623190 (A Model of Change for Preparing a New Generation for Professional Practice in Computer Science) and HRD-1242122 (Cyber-ShARE Center of Excellence).

The authors are greatly thankful to all the participants of the VI International Forum on Teacher Education (Kazan, Russia, May 27-29, 2020), especially to the authors of the paper [1], to Mourat Tchoshanov (University of Texas at El Paso) and to Gulshat Shakirova (Kazan Federal University, Russia), for valuable discussions.

\section{REFERENCES}

1. Shakirova K., Fazleeva E., and Timerbayeva N. Challenges in training beginning math teachers. Presented at the VI International Forum on Teacher Education, Kazan, Russia, May 27-29, 2020.

\section{СОВЕТ НОВЫМ ПРЕПОДАВАТЕЛЯМ: СИСТЕМНЫЙ ПОДХОД}

\author{
О. Кошелева \\ к.ф.-м.н., доцент, е-mail: olgak@utep.edu \\ В. Крейнович \\ к.ф.-м.н., профессор, e-mail: vladik@utep.edu \\ Техасский университет в Эль Пасо, США
}

\begin{abstract}
Аннотация. В недавней статье был представлен полезный системный подход для новых школьных учителей. В этой статье мы несколько изменяем этот совет, чтобы его можно было применять к новым преподавателям на всех уровнях, включая новых преподавателей на уровне университета.
\end{abstract}

Ключевые слова: новые инструкторы, системный подход, обучение. 